\title{
Usefulness of Hybrid Capture HPV DNA Assay as a Diagnostic Tool for Human Papillomavirus Infection
}

\author{
Takeyoshi KUBOTA ${ }^{1)}$, Kazuhisa ISHI $^{2)}$ Masaaki SUZUKI ${ }^{3)}$, \\ Sakae UTSUNO ${ }^{1)}$ and Jun IGARI ${ }^{2)}$ \\ ${ }^{1)}$ Department of Obstetrics and Gynecology, Juntendo University, Juntendo Urayasu Hospital \\ ${ }^{2}$ Department of Clinical Pathology, Juntendo University, School of Medicine \\ ${ }^{3)}$ Department of Obstetrics and Gynecology, Urayasu Ichikawa City Hospital \\ (Received: August 7, 1998) \\ (Accepted: September 21, 1998) \\ Key words: STD, human papillomavirus (HPV), hybrid capture assay, cervical \\ intraepithelial neoplasia, cervical cancer
}

\begin{abstract}
The purpose of this study was to determine the usefulness of the hybrid capture HPV DNA assay, a new nonradioactive solution hybridization assay, as a diagnostic tool for human papillomavirus infection. In a total of 234 women, samples for the hybrid capture assay and polymerase chain reaction (PCR) assay were obtained by wiping a swab across the cervix and external os (either a Dacron swab or a cotton swab was used). The papanicolaou smear test (Pap smear) was carried out on all 234 women. Tissue samples for biopsy were obtained by colposcopy from 118 of the women. Fisher exact test was used for statistical analyses. Using the hybrid capture assay, HPV DNA of high- and intermediate-oncogenic-risk type was detected in 23 (13.9\%) of 166 samples from women with Pap smear Class I or II, and 48 (70.6\%) of 68 with Pap smear Class III, IV or V ( $<<0.0001)$. The HPV DNA type was detected in 18 (29.0\%) of 62 samples from those with no evidence of cervical intraepithelial neoplasia and $44(78.6 \%)$ of 56 with cervical intraepithelial neoplasia or squamous cell carcinoma $(\mathrm{p}<0.0001)$. Correlation of the test results between the hybrid capture test and PCR was determined by using the 217 samples in which both test results were available (PCR test results were not obtainable in 17 samples. When PCR is set as a gold standard, the hybrid capture test has high sensitivity (74.6\%) and specificity (92.7\%). These findings suggest that the hybrid capture HPV DNA assay is a useful method for diagnosing HPV infection in the clinic.
\end{abstract}

\section{Introduction}

Among microorganisms causing sexually transmitted diseases (STD), the human papillomavirus (HPV) is recognized as the major cause of cervical cancer precursor lesions ${ }^{11}$. Early detection of HPV genital tract infection is important especially in asymptomatic individuals, because the majority of individuals with HPV genital tract infection do not present visible lesions. Since serologic assays and cell cultures are not available for detecting HPV infection, HPV DNA detection assays including the polymerase chain reaction (PCR), Southern blot, dot blot and in situ hybridization become important tools in the detection of HPV infection. Of these, PCR assay and Southern blots have higher

Correspondence to: Takeyoshi KUBOTA, M.D.

Department of Obstetrics and Gynecology, Juntendo University, Juntendo Urayasu Hospital 211 Tomioka Urayasucity Chiba 279-0021, Japan 
sensitivity and specificity ${ }^{1}$, however these are too complicated for routine clinical use. Dot blot is a rapid test, but has low sensitivity. Although in situ hybridization can detect the HPV location in the tissue, it has low sensitivity ${ }^{1) \sim 4}$. The hybrid capture HPV DNA assay (Digene Diagnostics, MD, USA) is a solution hybridization method in which ribonucleic acid (RNA) probes for HPV DNA are hybridized in solution with the sample $\mathrm{DNA}^{5}$.

We conducted a clinical study to determine the usefulness of the hybrid capture HPV DNA assay for detecting HPV DNA in the uterine cervix by comparing the detection rate using this method with that using the PCR method.

\section{Materials and Methods}

A total of 234 women were enrolled in this study. The women visited either the Department of Obstetrics and Gynecology, Juntendo Urayasu Hospital, Juntendo University or Urayasu Ichikawa City Hospital from October 1997 through March 1998. The purpose of the visit was evaluation of a previously abnormal Papanicolaous smear, follow-up after therapy for cervical intraepithelial neoplasia, or routine screening. Their ages ranged from 17 to 73 years (mean \pm SD; $41.5 \pm 11.0$ ). Papanicolaou smear test, hybrid capture assay and PCR assay were performed on these 234 patients with the patient's consent. The numbers of the patients with Papanicolaou smear Class I + II, IIIa, IIIb, and IV + V were 166, 37, 7 and 24, respectively. Colposcopy-guided cervical biopsy was performed in 118 of the 234 women, consisting of 62 with no evidence of cervical intraepithelial neoplasia (CIN), 18 with CIN grade I (CIN 1), 16 with CIN 2, 13 with CIN 3, and 9 with squamous cell carcinomas.

The samples for hybrid capture assay and PCR assay were obtained by firmly wiping a swab with a Dacron stick (207 specimens collected at Juntendo Urayasu Hospital) or a cotton swab (27 specimens collected at Urayasu Ichikawa City Hospital) across the cervix and external os. The swab was immediately placed into a specimen collection tube containing $1.0 \mathrm{ml}$ of specimen transport medium and stored at $-80^{\circ} \mathrm{C}$ until it was assayed. A Papanicolaou smear was obtained by the routine method before collecting the sample for hybrid capture.

Hybrid capture assay

The hybrid capture assay was performed according to the directions of the manufacturer. Briefly, in a micro tube, RNA probes were hybridized with HPV DNA which had been denatured in a sample collection tube. DNA and RNA hybrids were then placed onto the surface of a microplate coated with anti-DNA and RNA hybrid antibody, and reacted with another anti-DNA and RNA hybrid antibody mixture conjugated with alkaline phosphatase. The RNA-DNA hybrids were detected by chemiluminescence. Samples were considered to be positive if the index value (test sample value/positive control value) was $\geqq 1.0$, and negative if the index value was $<1.0$. The hybrid capture kit contains two separate HPV probe mixtures. One probe mixture, designated A, detects low-oncogenic-risk HPV types, incluidng types 6, 11, 42, 43, and 44. The other probe mixture, designated B, detects high- and intermediate-oncogenic-risk HPV types, including 16, 18, 31, 33, 35, 39, $45,51,52,56,58,59$ and 68 . In the present study, the positive rate was calculated by counting the specimen reacting with the probe $\mathrm{B}$.

PCR assay

DNA samples for PCR amplification were prepared from clinical specimens by phenol/chloroform extraction and ethanol precipitation. Two sets of L1 consensus primers, MY09/MY11 and Gp5+/Gp6+, were used for PCR. PCR conditions for MY09/MY11 primers were: 5 min preincubation at $95^{\circ} \mathrm{C}, 35$ thermal cycling with $60 \mathrm{sec}$ denaturation at $95^{\circ} \mathrm{C}, 2$ min annealing at $55^{\circ} \mathrm{C}$ and 2 min extension at $72^{\circ} \mathrm{C}$, then an additional 3 min incubation at $72^{\circ} \mathrm{C}$. The PCR conditions for Gp5+/ 
Gp6 + primers were: 40 thermal cycling with $60 \mathrm{sec}$ denaturation at $94^{\circ} \mathrm{C}, 2$ min annealing at $40^{\circ} \mathrm{C}$ and 1.5 min extention at $72^{\circ} \mathrm{C}$. After the amplification, $10 \mu \mathrm{l}$ of the PCR products was analyzed by $4 \%$ agarose gel electrophoresis and subsequent ethidium bromide staining. PCR with $\beta$-globin-specific primers which produce a 408 base pair product was also conducted to confirm correct sample preparation. Samples positive for either MY09/MY11 or Gp5+/Gp6 + were determined as HPV PCR-positive. The low-oncogenic-risk HPV types and high- and intermediate-oncogenic-risk HPV types can be detected by the use of these consensus primers.

Fisher's exact test was used for the statistical analyses.

\section{Results}

The positive rates of the hybrid capture assay and PCR method in different grades of the Pap test are shown in Table 1 . The positive rate in the group including Pap smear Classes III, IV $+\mathrm{V}$ was greater than that in the group including class I + II $(p<0.0001)$. Similar detection rates were obtained by the PCR method, and no significant differences were observed between the two methods (Table 1). The positive rates by hybrid capture assay in each group with no evidence of CIN, CIN grade 1 , CIN grade 2 , CIN grade 3 , or squamous cell carcinoma of the cervix are shown in Table 2 . The positive rate in the group including CIN grade 1,2 , and 3 and squamous cell carcinoma of the cervix was greater than that in the group with no no evidence of CIN $(p<0.0001)$. Similar detection rates were obtained by the PCR method, and no significant differences were observed between the two methods (Table 2). The results of PCR could not be obtained in 17 of 234 samples; 14 of the 17 $(82.4 \%)$ samples were collected with a cotton swab.

Correlation of the test results between the hybrid capture test and PCR was determined using the 217 samples in which both test results were available. When PCR was set as a gold standard, the hybrid capture test showed high sensitivity 74.6\% (50/67) and specificity 92.7\% (139/150). Among 61 cases positive by the hybrid capture test, 50 (82.0\%) were positive by PCR, and among 156 cases negative by the hybrid capture test 139 (89.1\%) were negative by PCR (Table 3 ).

\section{Discussion}

Cervical cancer is one of the most common, yet the most preventable, cancers among women. Among the microorganisms causing STD, specific types of HPV are associated with invasive cervical

Table 1 Positive rates for human papillomavirus by hybrid capture assay and PCR method in different grades of Papanicolaou test results

\begin{tabular}{|c|c|c|c|c|c|}
\hline & \multicolumn{5}{|c|}{ Papanicolaou smear test } \\
\hline & Class I + II & Class IIIa & Class IIIb & Class IV + V & Total \\
\hline $\begin{array}{l}\text { Positive rate } \\
\text { by Hybrid } \\
\text { Capture(\%) }\end{array}$ & $13.9(23 / 166)$ & $64.5(24 / 37)$ & $100.0(7 / 7)$ & $70.8(17 / 24)$ & $30.3(71 / 234)$ \\
\hline \multirow[t]{3}{*}{$\begin{array}{l}\text { Positive rate } \\
\text { by PCR }(\%)\end{array}$} & $17.4(28 / 161)$ & $69.0(20 / 29)$ & $75.0(3 / 4)$ & $69.6(16 / 23)$ & $30.9(67 / 217)$ \\
\hline & \multicolumn{5}{|c|}{ Papanicolaou smear test } \\
\hline & \multicolumn{2}{|c|}{ Class I + II } & Class IIIa $\sim \mathrm{V}$ & \multicolumn{2}{|r|}{$\mathrm{p}$ value } \\
\hline $\begin{array}{l}\text { Positive rate } \\
\text { by Hybrid } \\
\text { Capture(\%) }\end{array}$ & \multicolumn{2}{|c|}{$13.9(23 / 166)$} & $70.6(48 / 68)$ & \multicolumn{2}{|r|}{$\mathrm{p}<0.0001$} \\
\hline $\begin{array}{l}\text { Positive rate } \\
\text { by PCR(\%) }\end{array}$ & \multicolumn{2}{|c|}{$17.4(28 / 161)$} & $69.6(39 / 56)$ & \multicolumn{2}{|r|}{$\mathrm{p}<0.0001$} \\
\hline
\end{tabular}


Table 2 Positive rates for human papillomavirus by hybrid capture assay and PCR method in different grades of histopathological findings

\begin{tabular}{|c|c|c|c|c|c|c|}
\hline & \multicolumn{6}{|c|}{ Histopathological findings } \\
\hline & $\begin{array}{l}\text { No evidence } \\
\text { of CIN }\end{array}$ & CIN 1 & CIN 2 & CIN 3 & $\mathrm{SCC}$ & Total \\
\hline $\begin{array}{l}\text { Positive rate } \\
\text { by Hybrid } \\
\text { Capture(\%) }\end{array}$ & $29.0(18 / 62)$ & $55.6(10 / 18)$ & $93.8(15 / 16)$ & $84.6(11 / 13)$ & $88.9(8 / 9)$ & $52.5(62 / 118)$ \\
\hline \multirow[t]{3}{*}{$\begin{array}{l}\text { Positive rate } \\
\text { by PCR }(\%)\end{array}$} & $32.1(18 / 56)$ & $56.3(9 / 16)$ & $91.7(11 / 12)$ & $72.7(8 / 11)$ & $77.8(7 / 9)$ & $51.0(53 / 104)$ \\
\hline & \multicolumn{6}{|c|}{ Histopathological findings } \\
\hline & \multicolumn{2}{|c|}{$\begin{array}{l}\text { No evidence } \\
\text { of CIN }\end{array}$} & \multicolumn{2}{|c|}{$\mathrm{CIN} 1 \sim \mathrm{SCC}$} & \multicolumn{2}{|c|}{$\mathrm{p}$ value } \\
\hline $\begin{array}{l}\text { Positive rate } \\
\text { by Hybrid } \\
\text { Capture }(\%)\end{array}$ & \multicolumn{2}{|c|}{$29.0(18 / 62)$} & \multicolumn{2}{|c|}{$78.6(44 / 56)$} & \multicolumn{2}{|c|}{$\mathrm{p}<0.0001$} \\
\hline $\begin{array}{l}\text { Positive rate } \\
\text { by PCR }(\%)\end{array}$ & \multicolumn{2}{|c|}{$32.1(18 / 56)$} & \multicolumn{2}{|c|}{$72.9(35 / 48)$} & \multicolumn{2}{|c|}{$\mathrm{p}<0.0001$} \\
\hline
\end{tabular}

Table 3 Correlation of the test results between Hybrid Capture assay and PCR metod

\begin{tabular}{ccccc}
\hline & & \multicolumn{3}{c}{ Hybrid Capture(Probe B) } \\
\cline { 3 - 5 } & & + & - & Total \\
\hline \multirow{3}{*}{ PCR } & + & 50 & 17 & 67 \\
& - & 11 & 139 & 150 \\
& Total & 61 & 156 & 217 \\
\hline
\end{tabular}

cancers and their precursor lesions ${ }^{1)}$. Detection of HPV infection is important for predicting cervical cancer precursor lesions ${ }^{6}$. Since HPV infection occurs frequently concomitant with chlamydial and gonococcal infections ${ }^{7)}$, examination for HPV DNA is recommended together with Chlamydia trachomatis and Neisseria gonorrhoeae in patients suspected of having STD. Over 70 types of HPV are known, of which 18 types have been detected in specimens from the cervix ${ }^{3)}$. The hybrid capture assay is a nonradioactive assay that utilizes solution hybridization. The RNA probe mixture in this kit includes all the clinically important types of HPV DNA classified as intermediate to high risk types.

Using the hybrid capture assay, Sun ${ }^{8)}$ detected HPV DNA (by probe B only) in 78 (31\%) of 254 samples from women with no evidence of cervical intraepithelial neoplasia and in 120 (80\%) from 155 women with cervical intraepithelial neoplasia or cervical cancer. Using the same method, we detected HPV DNA in $18(29.0 \%)$ of 62 samples from women with no evidence of cervical intraepithelial neoplasia and $44(78.6 \%)$ of 56 samples from those with cervical intraepithelial neoplasia or cervical squamous cell carcinoma $(\mathrm{p}=0.0006)$. The positive rate increased as the cytological or histological abnormality increased. In a study of women who had attended STD clinic $^{9}$, a $28 \%$ of the women with HPV became CIN grade 2 or 3 two years later, while $3 \%$ of women without HPV became CIN grade 2 or 3 . This finding suggests that HPV infection is associated with malignant transformation of the cervical lesion. This kit may be useful for early detection of the transformation process from HPV infection, via a dysplasic stage, to invasive cancer.

Conventional HPV DNA detection methods are not widely used for clinical purpose because they 
require specific apparatus and equipment, involve complicated procedures, are time consuming, or are difficult to use with large numbers of clinical specimens. In contrast, the hybrid capture HPV DNA assay has several advantages over the other detection methods in terms of clinical application. A large number of clinical specimens can be tested, because it requires no special apparatus or equipment, the procedures are more convenient, and the whole assay can be completed in only three and a half hours.

PCR with consensus primers detects almost all the types of HPV DNA; hybrid capture detects low-oncogenic-risk-HPV type by probe A and high- and intermediate-oncogenic-risk-HPV type by probe B. Hybrid capture had high sensitivity (74.6\%) and specificity ( $92.7 \%$ ) by counting the positive cases reacting to probe $\mathrm{B}$ in the present analysis [when counting the positive cases reacting with probes $A$ and B, sensitivity was $82.0 \%$ (50/61) and specificity was $89.1 \%$ (139/156)]. Hybrid capture is a non-amplification method; however it had high sensitivity and specificity compared with PCR set as a gold standard, though 1) PCR has a significant problem of false positivity ${ }^{1)}$, 2) and sometimes the PCR result is not obtainable because of the incomplete removal of inhibitory substances in the specimen. In the present study, the results of PCR could not be obtained in some cases, in most of which a cotton swab with a wooden stick was used. It is suggested that certain kinds of inhibitory substances may not be removed by the DNA preparation procedure when a cotton swab with a wooden stick is used.

Regarding hybrid capture, false negativity should be considered in the cases in which PCR appears positive and hybrid capture appears negative, because the positive result by hybrid capture can be obtained only when the concentration of HPV DNA in a sample is greater than $1.0 \mathrm{pg} / \mathrm{ml}^{3}$. Cope (1997) reported that the sensitivity of the first generation hybrid capture tube method ${ }^{10)}$, with PCR used as the standard for HPV status, was higher for specimens from women with concurrent squamous intraepithelial lesions $(81.0 \%$ ) than for specimens from women with normal cytology (46.7\%) when the analysis was restricted to the 14 types detectable by both methods. Though our samples were not tested by the first generation hybrid capture tube method and our analysis was not restricted to the same types detectable by both methods, we had similar results; the sensitivity of hybrid capture, with PCR used as the standard for HPV status, was higher for specimens from women with Pap smear Class I or II $(60.7 \% ; 17 / 28)$ than for specimens from women with Pap smear Class III, IV or V $(86.8 \% ; 33 / 38)$. It should be borne in mind that a greater proportion of the patients with normal cytology in the total subjects makes the sensitivity lower.

In conclusion, our findings suggest that hybrid capture HPV DNA assay may become a standard detection method for diagnosing HPV infection in the clinical situation.

\section{References}

1) Trofatter KF Jr: Diagnosis of human papillomavirus genital tract infeciton. Am J Med 1997; 102: 21-27.

2) Ishi K, Suzuki F, Saito A, Kina K, Koyatsu J, Kubota T: Cytopathology and histopathology of human papilloma virus. Jpn J Clin Pathol. 1998; 46: 229-234.

3) Ishi K, Kina K, Utsuno S, Suzuki M, Kubota T, Jun Igari: Usefulness of hybrid-capture HPV DNA detection kit for the diagnosis of HPV infection. Jpn J Med Pharm Sci. 1998; 38: 849-853.

4) Kina K, Ishi K, Okuyama N, et al:: Detection of human papilloma virus DNA in archival cytologic specimens by in situ polymerase chain reaction. J Jpn Soc Clin Cytol 1997; 36: 473-477.

5) Lorinez A: Diagnosis of human papillomavirus infection by a new generation of molecular DNA assays. Clin Immunol News 1992; 12: 123-128.

6) Sasagawa T, Dong Y, Saijo K, Satke S, Tateno M, Inoue M: Human papillomavirus infection and risk determinants for squamous intraepithelial lesion and cervical cancer in Japan. Jpn. J. Cancer Res 1997; 88: 376-384.

7) Furugen Y, Utsuno S, Suzuki M, Kubota T, Takada M: Superinfections and problems in treatment of STD high risk group. JASTD, 14: 190-195, 1991. 
8) Sun XW, Fererczy A, Johnson D, et al:: Evaluation of the Hybrid Capture human papillomavirus deoxyribonucleic acid detection test. Am J Obstet Gynrcol 173: 1432-1437, 1995.

9) Koutsky LA, Holmes KK, Critchlow CE et al:: A chorot study of the risk of cervical intraepithelial neoplasia grade 2 or 3 in relatiion to papillomavirus infection. N Engl J Med 327: 1272-1278, 1992.

10) Cope JU, Hildesheim A, Schiffman MH et al.: Compariosn of the hybrid capture tube test and PCR for detection of human papillomavirus DNA in cervical specimens. J Clin Microbiol 35: 2262-2265, 1997.

\title{
Human papillomavirus 感染症診断における hybrid capture 法の有用性
}

\author{
1)順天堂大学医学部附属順天堂浦安病院産婦人科 \\ 2)順天堂大学医学部臨床病理 \\ 3)浦安市川市民病院産婦人科 \\ 久保田武美1) 石和 久 ${ }^{2)}$ 鈴木 $\quad$ 正明 ${ }^{3)}$ \\ 宇津野 栄 ${ }^{11}$ 猪狩 淳 ${ }^{21}$
}

\begin{abstract}
要旨
非放射線の液相ハイブリダイゼーションを用い たDNA 診断法である Hybrid Capture 法につい て Human papillomavirus (HPV) 感染症診断に おける有用性を検討した。検体は子宮頝部あるい は外子宮口をスワブで擦過することにより得られ た。中〜高リスク型 (Probe B) に属する HPV の 陽性率を求めた結果, 細胞診 Class I あるいは II の婦人では13/9\%(23/166)が, また, 細胞診 Class III, IV, V の婦人では70.6\% (48/68) が陽性を示
\end{abstract}

した $(\mathrm{p}<0.0001$, Fisher の直接法). 子宮䅡部上 皮内腫瘍の認められない例では29.0\% (18/62)が, また，子宮頝部上皮内腫瘍あるいは子宮癌例では 78.6\%(44/56) が陽性を示した $(\mathrm{p}<0.0001$, Fisher の直接法). Hybrid Capture 法と PCR 法との比 較（ $\mathrm{n}=217 ）$ において陽性一致例は $74.6 \%$, 陰性 一致例は $92.7 \%$ と良好であった. Hybrid Capture 法は臨床における HPV 感染症診断に有用である ことが示唆された。 